\title{
THE INFLUENCE OF SCHILLER'S POEMS ON THE DEVELOPMENT OF GERMAN THEATER IN THE XVIII CENTURY
}

\author{
Sodirjon Bakievich Yakubov
}

Associate Professor, Faculty Of Foreign Philology National University Named After Mirzo Ulugbek, Uzbekistan

\section{ABSTRACT}

The great German poet and playwright Friedrich Schiller was deeply involved in justice, medicine, aesthetics, history, logic, metaphysics, history of philosophy, and psychology, in addition to drama, because of his deep knowledge of Latin and Greek. With this research, Schiller tries to know human life on a materialistic basis. While Schiller studied dramaturgy from Shakespeare's work, the works of Voltaire, Diderot, Russo, Lessing, Goethe served to shape his worldview. His friendship with Goethe in particular had a profound effect on his creative potential.

Although in Schiller's work "Pirates" the style was varied (Shakespearean tragedy, specific to Baroque art, rhetorical to Russian works), it was the first lyrical drama to have a political orientation in German drama.

KEYWORDS: - Schiller, German theater, dramaturgy, "Pirates", "Cunning and Love”, "Maria Stewart".

\section{INTRODUCTION}

Friedrich Schiller wrote the play "Die Räuber" in 1781. The play was originally staged at the Mannheim Theater and was a huge success.

Schiller did not confine himself to the work of art, but studied in depth the problems of theater and he explains his ideas and aesthetic views in his theoretical works such as "On the modern German Theater" (Uber gegenwärtige deutsche Theater, 1782), "Does the theater provide spiritual nourishment" (Die Schaubuhne als eine moralische Anstalt betrachtet, 1785).
In Schiller's works, there is a worldview typical of Sturmers, that is, the writer believes that art should fight spiritually against the evils of society, serve to raise the consciousness of mankind. To do this, the dramatist says, he must openly describe the truth, the contradictions in society, and use a simple, lifelike writing style. Schiller criticizes works that are disguised as 'classic works', consisting only of praising the rulers, with luxurious, lavish, beautiful words. In particular, he criticized French theatrical art, which was in vogue at the time. He writes: In Paris, it was customary to bring on stage lazy puppets who would respond with 'gentle', always saying 'okay', but in fact trying to hide the truth. 
CURRENT RESEARCH JOURNAL OF PHILOLOGICAL SCIENCES 2(12):

201-205, December 2021

DOI: https://doi.org/10.37547/philological-crjps-02-12-38

ISSN 2767-3758

(C)2021 Master Journals

crossref do) :810 Google

Accepted21 ${ }^{\text {th }}$ December, 2021 \& Published $26^{\text {th }}$ December, 2021

\section{Methods}

Schiller advocates an entertaining, nurturing, enlightening theater. He believes that the negative events expressed through the scene do not hurt the human tongue, but encourage thought. Schiller's progressive views are, of course, influenced by the play "Hamburg Dramaturgy" by theater critic and writer Lessing. This is probably why Schiller's works followed the rules of dramaturgy, as perfect plays, as well as in line with the progressive ideas of the "Storm and Pressure" movement.

The main protagonist of the work "Pirates" Carl Moor openly "declares war on such a society." He hides in the forest of Bohemia with his bandits, disturbing the peace of all the oppressive rulers. Although the robbers appeared to be lawbreakers, their real intention was to punish the real robbers who amassed excessive wealth. They rebel in order to open the eyes of ministers and princes who go to extremes and use their positions for their own benefit. In the play, the conflict between the siblings leaves the family boundary and becomes a social problem. The collision is viewed on the same scale as Shakespeare's King Lear. But Schiller gives the images a brighter social meaning. For example, from a human point of view, Franz Moor is a criminal, but from the point of view of feudal society he is a man who defends his rights. So, Schiller wants to appoint: "humanity cannot be realized without destroying the order of a criminal society," in this work.

In the works of art, the vices of feudal rulers before Schiller were generally criticized, or individuals were portrayed in the form of ancient images, in the form of historical figures and "softened" so as not to "touch" anyone in office. Schiller, on the other hand, takes all the "familiar" rich people of his time, the real-life bureaucrats in his life. For example, in his work, he tries describes "a government adviser which takes a bribe and will put that person in office that whoever gives more or the believer's concern for the disappearance of the Inquisition, and who is actually causing the social problems".

It is noticeable that the young playwright made a slight mistake in some places. For example, Carl's hatred of the evils of society is expressed not through his behavior, but rather through his monologues. Also, Amalia's purpose is unclear, her speech is mostly rhetorical, which means that the image is incomplete.

Schiller developed as a dramatist and later wrote the play "Cunning and Love" (Kabale und Liebe). In this play, more dramatic rules are followed. The protagonists and events of the work are not tissue. The main conflict (confrontation) takes place between two classes - the courtiers and the ordinary educated man, the musician Miller's burger family.

Miller doesn't want to be related to them because he knows full well that there is crime under any wealth, and that the rich look down on the ordinary family. When President Walter was rude, he opened the door and appointed, "Yes, it is your job to solve the affairs of state, but I am the landlord. Therefore, I have to drive an immoral guest out of my house. Bey!" drives a man in a high position.

Ferdinand's image is also unique: even though he is from the palace, he does not like a broad-minded, prudent man, the rulers' pursuit of a position for their own benefit, the accumulation of wealth and power, and the disregard for others because of his fame. He even tells his father, "My worldview of happiness and fame is different from yours ... You are always ready to sacrifice someone to get a position".

Ferdinand loves Louise and fights for his love, even though he knows he will be defeated in an unequal 
CURRENT RESEARCH JOURNAL OF PHILOLOGICAL SCIENCES 2(12):

201-205, December 2021

DOI: https://doi.org/10.37547/philological-crjps-02-12-38

ISSN 2767-3758

(C)2021 Master Journals

Crossref do

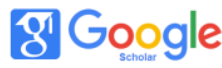

Accepted21 ${ }^{\text {th }}$ December, 2021 \& Published $26^{\text {th }}$ December, 2021

fight. But Schiller's mistake about Ferdinand's image: the dramatist did not show how Ferdinand, who grew up in the palace, had such a progressive reasoning.

Louise can think broadly and deeply. But her refuse to fight for her own happiness shows that his social background is not strong enough. Allowing for weakness, writing a letter causes all the tragedy. Still, the aspirations of young people in love are the first struggle against immorality. Schiller was able to reveal the character of the images in depth. They are not one-sided - 'bad' or 'good' people, but each has their strengths and weaknesses. Not only is musician Miller and his daughter suffering, but President Walter is also portrayed as a father who loved his son and a man who suffered greatly when his son died. Although Lady Milford is also a perverted woman, we feel that human pride is still preserved in her.

Thus, "Cunning and Love" is a work about how the government is trampling on the rights of the individual. Schiller does not shy away from the realities of life, he does not paint the conflict of love in the form of "happiness that disappears." Therefore, Ferdinand fights for his own happiness, not for the benefit of society. But his protest is a protest against injustice in society.

"Cunning and Love" is Schiller's last work in the Storm and Stress era. In his later work, Don Carlos (Don Carlos, 1787), one can be sure that there was a change in the artist's worldview. Don Carlos is an almost historical work based on the events of the 16th century in Spain: a feudal-Catholic reaction and a confrontation in the palace of Philip II, the Spanish ruler during the height of the Inquisition.

Schiller, like contemporary writers, praises hurricane, but recognizes only literature as the main weapon in the struggle for freedom, believing that works of art can change the human mind. Violence is also less conducive to revolutionary struggles, especially uprisings and rebellions, because it is against bloodshed.

Goethe is less able to digest Schiller's sturgeon-like dramas because he has previously backed away from the ideas of "Storm and Oppression" in relation to Schiller. Because Goethe had materialist views in philosophy, he did not support Schiller's adherence to Kant's philosophy, especially in his poems, in which he expressed ideas in an abstract style and used form in different positions. He believed that such views would negatively affect the author's creativity, as well as prevent the reader from understanding the idea of the work. Over time, Schiller understands Goethe's recommendations. He later wrote in a letter to Humboldt in 1796: "In one year I learned a great deal in my communication with Goethe, and both my human qualities grew and my creative ability increased".

In 1789, Schiller became professor of history at Yen University. Gave lectures on the topic "What is world history and for what purpose is it studied?". Influenced by the works of I. Kant, "On the tragedy in art" (1792), "On elegance and dignity", "On the ceremony" (1793), "Letters on the aesthetic education of man" (1795), "On simple and sentimental poetry" (1796). In these works, according to Schiller's interpretation, aesthetic education serves to stabilize human relations between people, forming in them humane qualities. The dramatic trilogy "Wallenstein" (Wallenstein, 1797-1799) is the highest work of Schiller. The writer has been working for many years and spends a lot of time and effort to find the right idea of the work, the form of its expression. According to the plot, Admiral Wallenstein allows his troops to plunder the enemy city. The reason is that he understands very well that soldiers who seek wealth do not leave the military. As long as there is 
CURRENT RESEARCH JOURNAL OF PHILOLOGICAL SCIENCES 2(12):

201-205, December 2021

DOI: https://doi.org/10.37547/philological-crjps-02-12-38

ISSN 2767-3758

(C2021 Master Journals

Crossref do

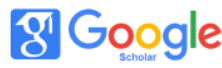

Accepted21 ${ }^{\text {th }}$ December, 2021 \& Published $26^{\text {th }}$ December, 2021

an army, the Austrian headquarters will not be able to oppose it. Taking advantage of this opportunity, Wallenstein can do whatever he wants.

Schiller's tragedy "Maria Stewart" (Maria Stewart, 1800) is a socio-psychological tragedy. The event takes place in the palace, note that one of the requirements of the drama - to solve the "event" in as many scenes as possible, indicates that the experience of the playwright has increased significantly. The author does not show the course of all events, but describes their hotspots. The drama of Maria Stewart has moved significantly away from historical realities. However, this did not diminish the artistic essence of the drama. On the contrary, the contradiction between the dream of building a free world and real reality formed the leading collision (contradiction) in Schiller's work. Schiller used compositions typical of Greek tragedy in this psycho-philosophical tragedy. The work begins with the events after the fate of Mary became known. That is, the death penalty should be announced, the execution should take place a few hours later ... Schiller does not cover politics, the trial and other historical events. We can learn from a few word of mouth of the protagonists that Maria Stewart was accused of killing her husband and was therefore removed from the Scottish throne.

The image of Maria is not 'innocent', she was condemned as a criminal, but she spent many years in a British prison, suffered a lot, meditated, and her worldview changed. He can express his opinion openly, correctly understand the hearts of the people around him, the reason for their actions. However, the slanders and accusations against Maria begin to bear fruit, and "more and more crimes" are placed on her shoulders in order to "aggravate" her previous crime.

In describing Mary's worldview, the author seeks to reveal the true face and secrets of her rival, Queen
Elizabeth. In no other work has Schiller expressed women's inner feelings so clearly. Along with revealing Maria's confrontations with Elizabeth, the playwright reveals the cause of the political and social conflicts in society. The policy, which seeks to preserve the novelty in society and the antiquity against it, seeks to portray the end of the conflict between the old era and the new era - an unavoidable tragedy, the author.

The play "Maria Stewart" is the most perfect dramatic work created at a time when Schiller's work was flourishing. It was after finishing this play that Schiller proudly declared, "Now I can say that I have become a dramatist". The composition of the play is well-constructed, the character of each character is fully revealed, the event at the beginning of the play is dramatic, as a result of the emergence of contradictions and its growth. The author did not use any artificial effects, did not try to show his skills, did not complicate it by adding beautiful "additions" to the work.

In the romantic tragedy The Maid of Orleans (Die Jungfrau von Orleans, 1801), Schiller first sought to portray the French people as heroes through the image of Janna d'Arc.

The hypocrisy of the priests was revealed: the clergy, who burned Janna d'Arc in the fire to lick it, and later declared her a saint, caused a great deal of controversy. In this way, Schiller further glorified the courage of Janna d'Arc.

In this play, the author consciously retreats from realism. It is therefore superior in terms of art. The dramatist continued his research in order to perfect the rules of pesa. It is no coincidence that Schiller called this work a romantic tragedy. In fact, the writer did not like the romantic style very much, but he used this style in order to intensify the contradictions. His other goal was to perfect this 
CURRENT RESEARCH JOURNAL OF PHILOLOGICAL SCIENCES 2(12):

201-205, December 2021

DOI: https://doi.org/10.37547/philological-crjps-02-12-38

ISSN 2767-3758

(C)2021 Master Journals

Crossref do

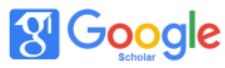

Accepted21 ${ }^{\text {th }}$ December, 2021 \& Published $26^{\text {th }}$ December, 2021

style in order to put an end to the ambiguities of the romantic style, the incompleteness of the form (which must have been influenced by Goethe's advice with Lessing's work). It is this work that has served as a school that helps to correct the shortcomings of artists who write in a romantic style, highlighting their own shortcomings. It is also written in the "Weimar Classics" style. We can see this from the fact that the image of the protagonist is portrayed in an ideal way, far from ordinary household chores.

Wilhelm Tell (Wilhelm Tell, 1804) is Schiller's last play. Schiller made his first comments on the great influence of the people on the changes and upheavals in history. In fact, Wilhelm Tell is a hero of the Swiss people who fought against the Austrian invaders. But the play also portrays the protagonist's weaknesses: he says in an interview with Steauffacher (the rebel), "Patience and silence are also courageous for me in this day and age". Or he says, "Whoever wants to live in peace, let him work peacefully at home." In this way, Schiller correctly revealed the character and mental state of an ordinary peasant boy, a young hunter.

Schiller's work, especially his plays, undoubtedly had a great influence on the development of German theater. When his mature dramatic works were brought on stage, he certainly delighted the audience, forcing them to think, to reflect. Schiller's works, such as those of Lessing and Goethe, created in the 18th century, influenced the change in the thinking of the German people and the emergence of a conscious society, as well as the development of theatrical art.

\section{REFERENCES}

1. N.A. Gulyaev, Literary trends and methods in Russian and foreign literature of the 17th-19th centuries. M.: Education, 1983.
2. N.A. Gulyaev, I.P. Shibanov, V.S. Bunyaev, N.T. Lopyrev, E.M. Mandel. History of German Literature. Moscow, "High School", 19753. K. Bottcher, H.J. Geerdts. R. Heukenkamp. Kurse Geschichte der deutchen Literatur, Volk und Wissen. Wolkseigener Verlag Berlin, 1983.

3. Ibragimova R.A. Literature of foreign countries in Uzbek. T., 1969.

4. Pulatov $\mathrm{Yu}$. On the study of foreign literature in Uzbekistan. "Teacher." Tashkent, 1975, p.3-28.

5. F.Shiller. "Pirates." A. Autonomous translation.

6. F.Shiller. "Deceit and love." Translated by K. Yashin and M. Hakim. T. 1936.

7. F.Shiller. "Maria Stewart" Full translation by T.

8. Sh.Karimov. Schiller and his epistolary legacy. World Literature, 2014, No. 11.

9. Lozinskaya L.Ya., Schiller, M., 1960;

10. A. Abush. Schiller: the greatness and tragedy of the German genius, M., 1964;

11. Lacknstein P. Schiller's Life, M., Raduga, 1984.

12. Peter-André Alt. Schiller. Leben-Werk-Zeit (2 Bände). Verlag C. H. Beck, München 2000.

13. Safranski. Schiller oder Die Erfindung des Deutschen Idealismus. Biographie. Hanser, München, 2004.

14. W.Noetzel. Friedrich Schillers Philosophie der Lebenskunst. Zur Ästhetischen Erziehung als einem Projekt der Moderne. Turnshare, London, 2006 